\title{
THE UNIQUENESS OF JESUS CHRIST AND PLURALISM FROM THE PERSPECTIVE OF THE REFORMED CONFESSION ${ }^{1}$
}

\author{
S.A. Strauss ${ }^{2}$
}

\section{ABSTRACT}

This article investigates the current issue of the relationship between Christian and non-Christian religions in multi-religious societies. The philosophical backgrounds of the pluralistic approach are summarised. Subsequently the (Dutch) Reformed confessions are scrutinised for Biblical guidelines which may be helpful in finding a solution for the problem of being Christians in a multi-religious society. It is argued that pluralism must be rejected, while both inclusivism and exclusivism can also not be accepted uncritically.

\section{PROBLEM STATEMENT}

The Collins English Dictionary (1999:1192; cf. Gensichen 1991) defines "pluralism" inter alia as "the existence in a society of groups having distinctive ethnic origin, cultural forms, religions, etc." This is a mere factual view of pluralism, which is found in most countries. This kind of pluralism has acquired the following ideological meaning in our time (McGrath 1994:448): The different religions are essentially equal and equally valid. In a democracy no discrimination against any religion is tolerated. The modern state should be neutral as far religion is concerned. Consequently, religious education in state schools and national religious broadcasts should also be neutral. Under no circumstances should legislation in respect of, for instance, Sundays and religious public holidays (Christmas, Easter, and so on) be based on religious grounds. According to the modern human rights ideology, no religious discrimination whatsoever is allowed.

The above dictionary gives the following meanings of the term "unique" (1999:1666; cf. Wainwright 1991): "1. Being the only one

1 An edited version of a paper read at a seminar of the Reformed Association in Seoul, South Korea on 18 September 2004.

2 Prof. S.A. Strauss, Faculty of Theology, University of the Free State, Bloemfontein, South Africa. 
of a particular type; single; sole. 2. Without equal or like; unparalleled". As Bible-believing Christians we have no option but to confess that our Lord and Saviour, Jesus Christ, is "unique" in this sense. This confession leads us to a direct confrontation with the abovementioned ideological pluralism. Consequently, numerous questions arise (cf. D'Costa 1993, 1997:627). May parliament or any other governmental meeting be opened by prayer? Are joint prayer meetings by members of different religions possible or even preferable? Is political collaboration with other religions regarding ethical issues, such as abortion, appropriate? Should we politically accept the principle of freedom of religion, while ecclesiastically and theologically upholding the principle of inequality of religions? Is such a dualistic philosophy of life (politics versus religion) acceptable for Christians?

These challenging, topical questions, and perhaps many others, necessitate a thorough investigation of the theme of pluralism and the uniqueness of Christ.

\section{DIFFERENT APPROACHES}

A relatively new sub-discipline has developed in the field of missiology, viz. the theology of religions. Students of this discipline have reached consensus that the issue of multi-religious societies and the relationship between the Christian and non-Christian religions can basically be approached in three different ways: exclusivism, inclusivism and pluralism (D'Costa 1997:627-31; McGrath 1994:458-64).

Exclusivism is almost similar to the traditional Protestant approach, according to which faith in Christ is the exclusive way whereby people can be saved. In this case, the starting-point is the Reformational solus Christus and sola fide. During the $20^{\text {th }}$ century two well-known theologians put their respective stamp on this approach.

Karl Barth (1886-1968), at least initially, distinguished radically between revelation and faith on the one hand, and religion on the other (Bosch 1991:478). The former is a gift of God, while the latter is created by sinful human beings. Essentially all religions, including Christianity, are merely attempts at self-redemption, and thus idolatry. Faith is, however, an unconditional acceptance of God's grace, which is of- 
fered to us in the gospel of Jesus Christ. Christ is the unique revelation of God and as such the exclusive way to redemption. ${ }^{3}$

In his famous publication Christian message in a non-Christian world (1938) Hendrik Kraemer (1888-1965) emphasised the uniqueness of God's revelation in Christ. This becomes evident in the acts of God throughout history. The climax is reached in the incarnation of Christ and the coming of the kingdom of God. Other religions may possess certain values and truths, but the unique Biblical truth must first be proclaimed to their followers; otherwise they remain lost.

Inclusivism is mainly attributed to the Roman Catholic theologian, Karl Rahner (1904-1984), who upholds the principle of solus Christus, thus recognising that Christendom is the absolute religion. According to him, however, another theological principle, the universal saving will of God, must also be considered. Non-Christian religions should also be able to mediate the grace of God, until the gospel of Christ is preached to their followers. The latter can thus be regarded as "anonymous Christians" — human beings who have received divine grace, without necessarily being aware thereof. Thus Christianity includes the other religions.

This inclusive approach is sometimes referred to as the fulfilment theory (Bosch 1991:479-81). As in the traditional Roman Catholic theology, the non-Christian religions (nature) are considered to be a preparation for the gospel (grace). Christ is then the fulfilment of all the other religions, just as He was the fulfilment of the Old Testament Jewish religion. Israel was indeed saved by Christ, although they did not know Him yet.

Pluralism is usually supported by liberal theologians. The British philosopher of religion, John Hick (1922-), gave new impetus to this movement. He argues that we need a theocentric revolution instead of a christocentric and an ecclesiocentric approach. All religions are in fact a variety of human responses to the one divine Reality. God's universal saving implies that all people should have equal opportunities to be saved (D'Costa 1997:628).

3 In his later career Barth had a more positive attitude towards the non-Christian religions as a result of his peculiar doctrine of election, which leant towards an undeniable universalism. The triumph of God's grace in Christ is so overwhelming that it becomes disputable whether anyone will be rejected eternally (Crafford 1996:224). 
In his book No other name (1985) Paul Knitter takes religious pluralism further. He is of the opinion that the essence of all religions lies in the common experience of liberation (D'Costa 1997:629). All religions are equally valid, and there can also be other redeemers than Jesus. As a consequence of his relativism, Knitter supports a broad ecumenicity. In this inter-religious dialogue no religion can claim absolute truth. Thus, missionary work (as a call of repentance to Christ) becomes totally superfluous.

\section{PHILOSOPHICAL BACKGROUNDS}

Like all theological theories, pluralism has an unmistakable philosophical background (Kauuova 1995:28ff.). In order to understand why theologians argue in a certain way, it may be worthwhile to investigate these backgrounds.

Since the Enlightenment, Western thought has been challenged by a secularistic view (McGrath 1994:450). Rationalism questioned supernatural miracles, and undermined the authority of the Bible. Rationalists also contended that all religions can in the last resort be reduced to the primordial rational religion of nature. The different religions are merely different pathways up the same mountain. At the summit one and the same Supreme Being is to be found.

F.D.E. Schleiermacher (1768-1834), the father of modern theology, sought a new rationality, which would be acceptable to modern man. For this purpose he took religion as his starting-point. The human experience of absolute dependence, which is accessible to all people, became the foundation of theology instead of the divine revelation which had become a problem for modern man. Theology was redefined as the science of religion. This line of thought was continued by Ludwig Feuerbach (1804-1872), who regarded religion as a projection of the human spirit. According to him, human beings designed their "god", who provided in their aspirations and fears. This reduction of theology to anthropology lasted until the $20^{\text {th }}$ century. Ernst Troeltsch (1865-1923), for instance, initiated a strong sociological approach in theology (Crafford 1996:221). In his research into the absoluteness of Christendom, he concluded, on "scientific" grounds, that every religion is historically and culturally determined to such an extent that none can claim absoluteness. Nevertheless, Christianity could be regarded 
as the highest form of religion, due to its civilising influence ("Kulturprotestantismus"!).

Even Hick's pluralistic view of religion is of a philosophical nature. According to the logical positivism or analytical philosophy of language, which he took over from L. Wittgenstein et al., all metaphysics should be rejected (Schulze 1981:79ff.). Religions are merely acquired means of talking about God. What is said about God is not objectively true, but it is rather a subjective commitment of how we would like to live. The incarnation and the doctrine of the two natures, for instance, are not factual statements but value judgements; they only express appreciation for Christ, and stimulate a positive attitude towards Him.

Currently the modernist paradigm is traded in for a postmodernist one (Strauss 1998b). This means, among others, that the absolute certainty of rationalism must be substituted by a relativistic uncertainty. Instead of universal truth, which holds good for all rational human beings, a particular perception is now being emphasised. Each one is entitled to his/her own opinion. As long as it is meaningful in his/her specific situation, it is acceptable. It becomes evident that pluralism will thrive in this atmosphere.

Hans Küng (1928-), a well-known theologian, has deliberately joined the postmodern movement (Strauss 1998a). He propagates an interreligious ecumenicity, in which a true dialogue will be conducted between the various religions. According to him, his approach recognises the plurality of religions; it is neither exclusivist, nor relativist, nor syncretistic. His ideal is: "optimal loyalty to one's own religious faith and maximal openness to others"!

\section{REFORMED GUIDELINES}

According to the reformed confession, there is only one criterion whereby we can judge whether points of view are acceptable or not, i.e. the Holy Scripture, which contains the will of God. This "infallible rule", the truth of God, "is above anything else" (B. Conf. 7). However, we undersign the reformed confessions quia (because) they correspond to the Word of God, and donec (until) the contrary has been thoroughly proven by the church in an orderly fashion. Therefore we are allowed to use the reformed confessions as norm - to be exact: norma normata (derived 
norm) - also in the evaluation of non-Christian religions. For this evaluation I use as my starting-point the Belgic Confession (1561), with reference to the other two reformed confessions of Dutch origin: the Heidelberg Catechism (1563) and the Canons of Dort (1619) (CRC 1988). The Belgic Confession, in its first article, mentions the confession that "there is a single and simple spiritual being, whom we call God". In article 8 it repeats that we believe in "one God, who is one single essence". In this statement, "single" is synonymous with "unique". ${ }^{4}$ The same is confessed concerning Jesus Christ, because "He is one in essence with the Father"; He is "the only Son of God, eternally begotten" (B. Conf. 10). The uniqueness of our Lord Jesus Christ rests upon his unique, single relationship with the unique, only God and Father. ${ }^{5}$ God (and His Son) is not one of a series, but the only One of his kind, sui generis.

As Jesus Christ is the unique Son of God, He could also accomplish a unique redemption for us. He appeased the wrath of God "with full satisfaction by offering himself." Therefore, we

find all comforts in his wounds and have no need to seek or invent any other means to reconcile ourselves with God than this one and only sacrifice which renders believers perfect forever (B. Conf. 21).

The atonement of Christ, completely perfect, is so entirely sufficient, that we have no option but to trust this wholeheartedly. This is literally an issue of everything or nothing. In doxological amazement we confess (B. Conf. 22):

For it must necessarily follow that either all that is required for our salvation is not in Christ or, if all is in him, then he who has Christ by faith has his salvation entirely. Therefore, to say that Christ is not enough but that something else is needed as well is a most enormous

4 Cf. the confession of old Israel: "The Lord our God, the Lord is one" (Deut. 6:4). Isaiah also confesses God's incomparability (Is. 40:25). This corresponds with the New Testament conviction: "There is no God but one ... for us there is but one God ... and there is but one Lord, Jesus Christ" (1 Cor. 8:4-6). Although idols are nothing, they are still dangerous: "The sacrifices of pagans are offered to demons" (1 Cor. 10:19f.).

5 The same is confessed concerning God in the H. Cat. 34:94 and 95: In the first commandment I am ordered "that I sincerely acknowledge the only true God, trust Him alone etc." And in H. Cat. 13:33 it is stated that "Christ alone is the eternal, natural Son of God". 
blasphemy against God — for it then would follow that Jesus Christ is only half a Saviour.

Similar jubilant sounds are echoed in H. Cat. 11:30:

Do those who look for their salvation and security in saints, in themselves, or elsewhere really believe in the only saviour Jesus? Although they boast of being his, by their deeds they deny the only saviour and deliverer, Jesus. Either Jesus is not a perfect saviour, or those who in true faith accept this saviour have in him all they need for their salvation. ${ }^{6}$

Does Christ's complete atonement also imply a general, universal atonement for all humankind? The H. Cat (7:20) denies this explicitly: "No. Only those are saved who by true faith are grafted into Christ ..." The same truth can also be expressed differently: The Son of God "gathers, protects and preserves for Himself a community chosen for eternal life ..." (H. Cat. 21:54). The Reformed confession states the Biblical truth of election. The B. Conf. (16) states emphatically: Because

all Adam's descendants having thus fallen in perdition and ruin ... God showed himself to be as He is: merciful and just ... He is merciful in withdrawing and saving from this perdition those whom he, in his eternal and unchangeable counsel, has elected and chosen in Jesus Christ our Lord by his pure goodness, without any consideration of their works.

This is later dealt with extensively in the Canons of Dort. Exactly how the reformed view predestination can be read in the first chapter of the Canons. The complex issue of whether Christ died for all, or only for the elect is of specific interest. The Canons of Dort provide a cautious, not one-sided, but balanced answer: "The death of God's Son $\ldots$ is of infinite value and worth, more than sufficient for the sins of the whole world" (2:3). Although being of value for all people,

it was God's will that Christ ... should effectively redeem from every people, tribe, nation, and language all those and only those who were chosen from eternity to salvation ... (2:8).

6 Without elaborating too much, I can briefly refer to the following consequences of Christ's unique atonement: (i) He is the only Intercessor. "Let us not leave Him for another - or rather seek, without ever finding." (B. Conf. 26); (ii) Because He is the only Saviour, "there is no salvation apart from" the church, his body (B. Conf. 28); (iii) Christ instituted baptism, by which "we are received into God's church and set apart from all other people and alien religions" (B. Conf. 34). 
From a reformed perspective, therefore, no general atonement is possible. Nevertheless, a general offer of grace is a fact.

The promise of the gospel, that whoever believes in Christ crucified shall not perish but have eternal life ... together with the command to repent and believe, ought to be announced and declared without differentiation or discrimination to all nations and people, to whom God in his good pleasure sends the gospel (2:5).

Another confessional truth that can shed light on the issue of general atonement, is the reformed answer to the soteriological question: "How can we be saved?" The H. Cat. (23:60) provides an unambiguous answer: "Only by true faith in Jesus Christ." The reformational sola fide diametrically opposes any meritoriousness of good deeds. H. Cat. 24:62 asks: "Why can't the good we do make us right with God?" The answer to this again refers to the unique, complete, perfect righteousness, which is to be found exclusively in Jesus Christ:

Because the righteousness which can pass God's scrutiny, must be entirely perfect ... Even the very best we do in this life is imperfect and stained with sin.

Non-meritorious good deeds do not cancel their necessity. Although we are saved sola gratia (by God's grace alone) and sola fide (through faith in Christ alone), good deeds are still expected from us. Christ does not "redeem" us only by his blood, but also "renews" us by his Spirit, so that we can thankfully praise God, may be assured of our faith by its fruits, and win over to Christ our neighbours (H. Cat. 32:86). The implication is clear: no "impenitent" person can be saved (H. Cat. 32:87). And those who do not believe cannot perform good deeds, because "good" in this case refers to "only that which arises out of true faith" (H. Cat. 33:91). Unequivocally stated:

7 For the sake of doctrinal purity, note the following pure reformational formulation in H. Cat. 23:60:

Even though my conscience accuses me of having grievously sinned against all God's commandments and of never having kept any of them, and even though I am still inclined toward all evil, nevertheless, without my deserving it at all, out of sheer grace, God grants and credits to me the perfect satisfaction, righteousness, and holiness of Christ, as if I had never sinned nor been a sinner, as if I had been as perfectly obedient as Christ was obedient for me. All I need to do is to accept this gift of God with a believing heart.

Pay specific attention to the phrases: "even though", "nevertheless", and "as if I". 
The kingdom of heaven is opened by proclaiming and publicly declaring to all believers, each and every one, that, as often as they accept the gospel promise in true faith, God, because of what Christ has done, truly forgives all their sins. The kingdom of heaven is closed, however, by proclaiming and publicly declaring to unbelievers and hypocrites that, as long as they do not repent, the anger of God and eternal condemnation rest on them (H. Cat. 31:84).

Although only the elect, i.e. the believers in Christ, are saved, this does not imply that God is only their God. He reigns with his providence over all people, believers and non-believers - even the devils! B. Conf. 13:

He watches over us with fatherly care, keeping all creatures under his control .... In this thought we rest, knowing that he holds in check the devils and all our enemies...

Because He created everything and everyone, I can trust in his care for me (H. Cat. 9). His providence is

the almighty and ever present power of God by which he upholds, as with his hand, heaven and earth and all creatures, and so rules them that all things, in fact, come to us not by chance but from his fatherly hand (H. Cat. 10:27).

God is no tribal god, but Creator and Sustainer of heaven and earth, of everything and everyone that exists. Therefore, his Son, our Lord Jesus Christ, has cosmic significance. That $\mathrm{He}$ is seated at the right hand of the Father means that He is not only "head of his church", but also the One through whom "the Father rules all things" (H. Cat. 19:50). ${ }^{8}$

Some theologians call this sole rule of God "common (or general) grace", whereas others have a problem with this. The concept of "general revelation" fits in the theological system general versus special. Although we do not have to accept this system or terminology, this issue features undoubtedly in our reformed confessions. The B. Conf. 2 states that we know God "by two means":

First, by the creation, preservation, and government of the universe, since that universe is before our eyes like a beautiful book in which all creatures, great and small, are as letters to make us ponder the invisible things of God: his eternal power and his divinity, as the apostle Paul says in Romans 1:20.

8 The H. Cat. in this case refers to the touching and all-encompassing expressions as in Math. 28:18; Eph. 1:20-23; Col. 1:18. 
In addition, "All these things are enough to convict men and to leave them without excuse."

The Canons of Dort 3/4:4 cautiously state the same truth:

There is, to be sure, certain light of nature remaining in man after the fall, by virtue of which he retains some notions about God, natural things, and the difference between what is moral and immoral, and demonstrates a certain eagerness for virtue and for good outward behaviour. But this light of nature is far from enabling man to come to a saving knowledge of God and conversion to him - so far, in fact, that man does not use it rightly even in matters of nature and society. Instead, in various ways he completely distorts this light, whatever its precise character, and suppresses it in unrighteousness. In doing so he renders himself without excuse before God.

The context of this paragraph must be taken into account, viz. the fall into sin with all its disastrous consequences. Humankind, who was created holy, fell into sin totally and radically (Canons of Dort 3/4:1). Because this corruption spread to all humankind (Canons of Dort 3/4:2), a logical conclusion can be drawn:

All people are conceived in sin and are born children of wrath, unfit for any saving good, inclined to evil, dead in their sins, and slaves to sin; without the grace of the regenerating Holy Spirit they are neither willing nor able to return to God, to reform their distorted nature .... (Canons of Dort 3/4:3).

The gospel, however, mercifully witnesses that God, "by the power of the Holy Spirit, through the Word or the ministry of reconcialition", accomplishes the totally impossible (Canons of Dort 3/4:6). According to the reformed confession, God revealed Himself to all people, believers and non-believers (also cf. Rom. 1:20; 2:15). God's revelation was good, but all humankind, being sinful and corrupt, distorts this revelation. It has no value other than to condemn them before God. They knew they had to worship and serve the only true God, but they were reluctant to do so.

\section{POSSIBLE SOLUTIONS}

In reflecting on the reformed confession, rooted in the Biblical message, one has no other option but to reject religious pluralism. The witness of Scripture on the uniqueness and absoluteness of Jesus Christ and his salvation is too overwhelming. The well-pitched phrases resound 
in the heart of each Bible-believing Christian: "I am the way and the truth and the life. No one comes to the Father except through me" (John 14:6). "Salvation is found in no one else, for there is no other name under heaven given to men by which we must be saved" (Acts 4:12). If one allows oneself to be guided by these truths of Scripture - also in one's argumentation - pluralism is exposed for what it actually is: a secular, modern, philosophical science of religion, built on unbelief in essence, and further empowering this unbelief.

The inclusivist approach is also unacceptable for the reformed. The doctrine of the universal saving will of God, which underlies it, comes in the disguise of piety, but it is certainly not Biblically inspired. Our confession calls to mind the Biblical truth of the total depravity and doom of all humankind. Those who admit this can expect redemption only by the grace of God - that grace which alone can accomplish the miracle of regeneration and conversion, justification and sanctification. And on whom does God shower this grace? Scripture is clear on this issue: only the elect, those whom God in his goodwill predestined before the creation of the world to belong to Him (Eph. 1:3ff.).

There is still a mystery: who has been elected and who has not? Therefore, we are responsible for spreading the gospel to all humankind. God's offer of grace is well meant: everyone who believes in Jesus Christ will be saved. As a matter of fact, we cannot provide answers to all the potential questions. What is the eternal destination of the millions of non-believers who never had the opportunity of hearing the gospel? We simply do not know. It also does not pay to grasp at man-made explanations. Once again, we simply do not know. We can only believe God's revelation in his Word: true faith is a condition for salvation. Apart from Christ equals apart from redemption. If not, why should the gospel be preached in any case? However, all people may be left in the hands of God, because He is merciful. "Let us fall into the hands of the Lord, for his mercy is great; but do not let me fall into the hands of men" (2 Sam. 24:14).

Should we then accept exclusivism as the correct perspective on the relationship between Christian and non-Christian religions? This point of view is, as a matter of fact, very close to our own. It at least makes allowance for the uniqueness and absoluteness of Jesus Christ. But the suffix "-ism" serves as a warning. All -isms denote one-sidedness. If 
exclusivism in practice should imply the inferiority of other religions, it could lead to a non-Christian attitude towards their followers. Someone who knows that $\mathrm{s} / \mathrm{he}$ has been saved by grace alone will never think of him-/herself as superior to others. We cannot isolate ourselves from other religions, because then we will not have the opportunity of reaching them with the gospel. This is the opinion of other reformed theologians such as Lesslie Newbigin (2003), D.J. Bosch (1991), and the report of the REC (1996). To uphold the principle of the uniqueness and absoluteness of Jesus Christ does not exclude the practice of conversation with the followers of other religions. ${ }^{9}$ As God created all humankind and still sustains it, and because He has commanded us to preach the gospel to all creation, we have to show our love, friendship and gentleness to all people - not only to fellow believers (cf. Rom. 12:18; Gal. 6:10; Phil. 4:5, to mention but a few well-known apostolic exhortations).

It is more difficult to provide sufficient answers to the political questions I posed at the beginning of this article. Local context will play a decisive role. Nevertheless, on the basis of the Biblical contents of our reformed confession, we should adhere to the fact that only God, in and through Jesus Christ, rules the world, both ecclesiastically and politically. Without causing a schism between religion and politics, we should draw a careful distinction between them. Co-operation, which is impossible in the sphere of religion, could be practically preferable in the sphere of politics. There is the example of Joseph and Daniel in the Bible, who occupied prominent and influential positions in pagan countries. The Lord also instructed his prophet Jeremiah to write to his people in the ungodly Babel concerning their participation in public life, and adds:

Seek the peace and prosperity of the city to which I have carried you into exile. Pray to the Lord for it, because if it prospers, you too will prosper (Jer. 29:7).

Also compare the New Testament command to pray for heathen kings and authorities (1 Tim. 2:1-4). I am aware of Paul's warning in 2 Cor. 6:14ff.:

9 Whether "conversation" also implies "dialogue" wholly depends on how the concept "dialogue" is defined and understood. 
Do not be yoked together with unbelievers. For what do righteousness and wickedness have in common? Or what fellowship can light have with darkness? What harmony is there between Christ and Belial? What does a believer have in common with an unbeliever?

The antithesis between light and darkness should often be maintained explicitly. But Paul also states in 1 Cor. 5:9-10 that Christians cannot always avoid all unbelievers. "In that case you would have to leave this world". And that is contrary to our calling to be the light of the world! I think the latter quotation reveals Paul as a sober, wise man of God.

We are commissioned to do two things simultaneously: "speaking the truth in love" (Eph. 4:15). We dare not compromise the truth of Jesus Christ's uniqueness in any way. But we must witness to all people about his salvation with an attitude of sincere Christian love.

\section{BIBLIOGRAPHY}

Bosch, D.J.

1991. Transforming mission. New York: Maryknoll.

Collins ENGLish Dictionary

1999. Harper Collins Publishers: $s l$.

CRAFFORD, D.

1996. Teologie van die godsdienste. In: P. Meiring 1996:220-234.

CRC

1988. Ecumenical creeds and reformed confessions. Grand Rapids: Christian Reformed Church Publications.

D'Costa, G.

1993. Other faiths and Christianity. In: A. McGrath 1993:411-418.

1997. Theology of religions. In: D.F. Ford 1997:627-641.

FORD, D.F.

1997. The modern theologians. Second edition. Oxford: Blackwell. 
GENSICHEN, H.

1991. Pluralism. In: N. Lossky et al. 1991:801-802.

KauUOVA, W.R.

1995. Religious pluralism as a challenge to the church in Southern Africa. Unpublished M.A. dissertation. (Supervisor Prof. S.A. Strauss.) Bloemfontein: University of the Orange Free State.

LOsSKY, N. et al (EDS.)

1991. Dictionary of the ecumenical movement. Grand Rapids: William B. Eerdmans.

McGrath, A.E. (ED.)

1993. The Blackwell encyclopedia of modern Christian thought. Oxford: Blackwell.

McGrath, Alister E.

1994. Christian theology. Oxford: Blackwell.

MEIRING, P. (ED.)

1996. Suid-Afrika, land van baie godsdienste. Pretoria: Kagiso.

Newbigin, L.

2003. Signs amid the rubble (Edited and introduced by G. Wainwright). Grand Rapids: William B. Eerdmans.

REC

1996. The unique person and work of Christ. Grand Rapids: Reformed Ecumenical Council.

SCHULZE, L.F.

1981. Teologie in stroomversnellings. Potchefstroom: Potchefstroomse Teologiese Publikasies.

STRAUSS, S.A.

1998a. Hans Küng se voorstel vir 'n eietydse etiek. In die Skriflig 32(4):487-500.

1998b. Gereformeerde teologie tussen modernisme en postmodernisme. Tydskrif vir Christelike Wetenskap. Spesiale Uitgawe April 1998:95-106.

The Holy Bible. New International Version

1991. Cape Town: Bible Society of South Africa.

WAINRIGHT, G.

1991. Uniqueness of Christ. In: N. Lossky et al. 1991:1030-1031. 
Strauss

Keywords

Jesus Christ

Uniqueness

Pluralism

Reformed confession
The uniqueness of Jesus Christ and pluralism

Trefwoorde

Jesus Christus

Uniekheid

Pluralisme

Gereformeerde belydenis 